\title{
Sensitivity to Acid of the Type Antigens of Streptococcus faecalis
}

\author{
By W. R. MAXTED AND CHERRY A. M. FRASER \\ Streptococcus Reference Laboratory, Colindale, London, N.W. 9
}

(Received 15 October 1965)

\begin{abstract}
SUMMARY
Extracts of Streptococcus faecalis cultures made with $0.01 \mathrm{~N}-\mathrm{HCl}$ gave a precipitin reaction with type antisera. With $0.05 \mathrm{~N}-\mathrm{HCl}$, however, some cultures gave inactive extracts. Part of the type-specific polysaccharide is converted by the strong acid to a form in which it does not precipitate with homologous sera, but which specifically inhibits the reaction between antibody and unaltered antigen.
\end{abstract}

\section{INTRODUCTION}

During a study of Streptococcus faecalis cultures isolated from human sources we used the serological typing method described by Sharpe \& Shattock (1952). We were able eventually to type $92 \%$ of the cultures, though we failed in nearly $40 \%$ when we used $0.05 \mathrm{~N}-\mathrm{HCl}$ for extracting the antigen (Maxted \& Fraser, 1964). This prompted a more detailed investigation of the optimal conditions under which the type-specific antigen can be separated from the bacteria.

\section{METHODS}

Organisms. Collections of cultures were received from four London hospitals. They had been isolated from a variety of human sources, including urine, faeces, blood and wound swabs. A further 11 strains from dental lesions were provided by Professor K. C. Winkler (Utrecht). In all, 267 cultures satisfied our criteria for Streptococcus faecalis; they belonged to group D, were resistant to $60^{\circ}$ for $30 \mathrm{~min}$., grew on tellurite media, reduced tetrazolium salts and did not ferment arabinose.

Antisera. Formalized vaccines of eight type strains $(1,3,4,5,6,8,9,19)$ were prepared from cultures provided by Dr M. E. Sharpe, by the method of Sharpe \& Shattock (1952). Vaccine was given in $1 \mathrm{ml}$. doses intravenously to rabbits at 3- to 4-day intervals and test bleedings were taken from 3 weeks onwards. After 6 weeks the sera usually gave a strong precipitin reaction with homologous cultures in a ring test, and had a titre of not less than $1 / 128$ by slide agglutination. Heterologous reactions were removed by absorption with suspensions prepared by heating a 48-hr broth culture at $70^{\circ}$ for $30 \mathrm{~min}$. and washing the organisms three times in saline. One volume of packed bacteria was added to 2 volumes of antiserum and the mixture incubated at $37^{\circ}$ for $2 \mathrm{hr}$ and left overnight at $4^{\circ}$ before centrifugation.

Extraction with acid. The centrifuged deposit of bacteria from $50 \mathrm{ml}$. of $0.5 \%$ glucose nutrient broth culture was heated for $10 \mathrm{~min}$. in a boiling water-bath with $2 \mathrm{ml} . \mathrm{HCl}$ of the requisite strength, and then neutralized with $0.05 \mathrm{~N}-\mathrm{NaOH}$.

Ethanol and acetone precipitation. After centrifugation, acid extracts were treated 
with $2 \frac{1}{2}$ volumes of acid ethanol $(1 \% \mathrm{HCl}$ in $95 \%$ ethanol in water), and left overnight at $4^{\circ}$. The precipitate was removed and taken up in $2 \mathrm{ml} . \mathrm{M} / 15$ phosphate

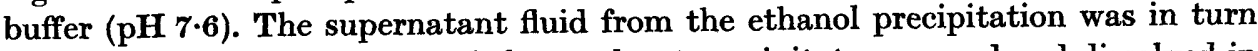
mixed with $2 \frac{1}{2}$ vol. acetone and the resultant precipitate removed and dissolved in 2 ml. phosphate buffer ( $\mathrm{pH} 7 \cdot 6)$.

Extraction with streptomyces enzyme. The centrifuged deposit of bacteria from $50 \mathrm{ml}$. glucose broth culture was heated to $70^{\circ}$ for $10 \mathrm{~min}$. and then lysed by suspending in a crude streptomyces enzyme solution for $2 \mathrm{hr}$ at $50^{\circ}$ (Maxted, 1948).

Extraction with lysozyme. Overnight cultures in glucose broth were heated at $80^{\circ}$ for $\frac{1}{2} \mathrm{hr}$ and centrifuged, the deposit washed three times with saline and suspended in lysozyme solution ( $1 \mathrm{mg} . / \mathrm{ml}$.) in saline, and adjusted to $\mathrm{pH} \mathrm{7.5}$. After $3 \mathrm{hr}$ at $37^{\circ}$ the $\mathrm{pH}$ value was raised to $9 \cdot 2$, the fluid centrifuged, and the supernatant fluid readjusted to $\mathrm{pH} \mathbf{7 \cdot 5}$.

Mechanical disruption of bacteria. The centrifuged deposit from $250 \mathrm{ml}$. of glucose broth culture was suspended in $5 \mathrm{ml}$. phosphate buffer $(\mathrm{pH} \mathrm{7 \cdot 6})$ and shaken with ballotini No. 12 in a Mickle disintegrator. The cell-wall fraction was removed by high-speed centrifugation.

\section{RESULTS}

Extracts of 267 strains of Streptococcus faecalis were made by boiling with 0.05 $\mathrm{N}-\mathrm{HCl} ; \mathbf{1 5 8}$ of them reacted with one of the eight type sera in the capillary precipitin test. The extracts of the 109 untypable cultures were treated with acid ethanol. The resulting precipitate was dissolved in buffer and tested with the type sera. A further 87 cultures then gave a type-specific precipitin reaction (Table 1 ).

Table 1. Serological typing of Streptococcus faecalis strains from human sources

\begin{tabular}{|c|c|c|c|c|c|c|c|c|c|c|c|}
\hline & \multirow[b]{2}{*}{$\begin{array}{l}\text { Number } \\
\text { tested }\end{array}$} & \multirow[b]{2}{*}{$\begin{array}{l}\text { Number } \\
\text { typable }\end{array}$} & \multicolumn{8}{|c|}{ Type } & \multirow[b]{2}{*}{$\begin{array}{c}\text { Not } \\
\text { typable }\end{array}$} \\
\hline & & & $\mathbf{1}$ & 3 & 4 & 5 & 6 & 8 & 9 & 19 & \\
\hline $\begin{array}{l}\text { Routine method: } 0.05 \mathrm{~N}-\mathrm{HCl} \\
\text { extract }\end{array}$ & $\mathbf{2 6 7}$ & 158 & 14 & 23 & 7 & 11 & 23 & $\mathbf{0}$ & $\mathbf{5 0}$ & 30 & 109 \\
\hline $\begin{array}{l}\text { Acid extract non-reactive: retested } \\
\text { after precipitation with ethanol }\end{array}$ & 109 & 87 & 51 & 6 & 1 & 10 & 6 & $\mathbf{0}$ & 2 & 11 & 22 \\
\hline Totals & & & 65 & 29 & 8 & 21 & 29 & $\mathbf{0}$ & $\mathbf{5 2}$ & 41 & \\
\hline
\end{tabular}

Acetone-precipitates from these cultures were redissolved in buffer and added to solutions of the ethanol-insoluble material. This prevented the type-specific reaction. The failure of $0.05 \mathrm{~N}-\mathrm{HCl}$ extract $(\mathrm{pH} \mathrm{1.6)}$ ) of some cultures to form a specific precipitate was therefore due to the presence of an inhibitory substance which was soluble in ethanol but precipitable by acetone.

When weaker strengths of hydrochloric acid were used for the initial extraction, the number of positive reactions was increased. Indeed, all cultures that were typable under any circumstances with one of the eight sera gave an active extract with $0.01 \mathrm{~N}-\mathrm{HCl}(\mathrm{pH} \mathrm{2 \cdot 4})$. This strength of $\mathrm{HCl}$ is therefore to be recommended for the routine typing method. Table 2 shows the serological reactions obtained with extracts made with a range of $\mathrm{HCl}$ concentrations. The two strains are of different serological types and show a marked difference in the resistance of their poly- 
saccharide type antigen to acid hydrolysis. All typable strains also gave serologically active extracts with Streptomyces enzyme and with lysozyme. Some serologically active polysaccharide could be obtained simply by shaking the deposited culture with water.

Table 2. Effect of strength of $\mathrm{HCl}$ on the extraction of active type-specific polysaccharide from Streptococcus faecalis

$\begin{array}{ccc}\text { Extracted with } & \overbrace{\text { No. } 28 \text { type } 1}^{\text {Type reaction of strain }} & \text { No. } 30 \text { type } 6 \\ \text { Water } & ++ & ++ \\ \text { HCl 0.01 N } & ++++ & ++++ \\ 0.03 \mathrm{~N} & + & +++ \\ 0.05 \mathrm{~N} & - & +++ \\ 0.1 \mathrm{~N} & - & +++ \\ 0.2 \mathrm{~N} & - & \pm\end{array}$

Table 3. Type-specific inhibition by $0.2 \mathrm{~N}-\mathrm{HCl}$ extract of Streptococcus faecalis of precipitin reaction between $0.05 \mathrm{~N}-\mathrm{HCl}$ extract and its homologous serum

\begin{tabular}{|c|c|c|c|c|c|c|c|c|}
\hline \multirow{2}{*}{$\begin{array}{c}\text { Homologous } \\
\text { type serum } \\
+\mathrm{HCl} \\
\text { extracts of } \\
\text { (undiluted) }\end{array}$} & \multicolumn{8}{|c|}{ Serum tested with $0.05 \mathrm{~N}-\mathrm{HCl}$ extracts of type } \\
\hline & $\mathbf{1}$ & $\mathbf{3}$ & 4 & $\mathbf{5}$ & 6 & 8 & $\mathbf{9}$ & 19 \\
\hline & \multicolumn{8}{|c|}{ Precipitin reaction } \\
\hline $\begin{array}{l}\text { T1 } \\
\text { T3 } \\
\text { T4 } \\
\text { T5 } \\
\text { T6 } \\
\text { T8 } \\
\text { T9 } \\
\text { T19 }\end{array}$ & $\begin{array}{c}- \\
++ \\
++ \\
++ \\
++ \\
++ \\
++ \\
++\end{array}$ & $\begin{array}{c}++ \\
- \\
++ \\
++ \\
- \\
++ \\
++ \\
++\end{array}$ & $\begin{array}{l}++ \\
++ \\
- \\
++ \\
++ \\
++ \\
++ \\
++\end{array}$ & $\begin{array}{c}++ \\
++ \\
++ \\
- \\
++ \\
++ \\
++ \\
++\end{array}$ & $\begin{array}{c}++ \\
++ \\
++ \\
++ \\
- \\
+++ \\
++ \\
++\end{array}$ & $\begin{array}{c}++ \\
++ \\
++ \\
++ \\
++ \\
+++ \\
++ \\
++\end{array}$ & $\begin{array}{c}++ \\
++ \\
++ \\
- \\
++ \\
+++ \\
- \\
++\end{array}$ & $\begin{array}{l}++ \\
++ \\
++ \\
++ \\
++ \\
++ \\
++ \\
-\end{array}$ \\
\hline
\end{tabular}

+ to $++++=$ strength of precipitation reaction with homologous type serum.

The effect of 0.05 and $0.01 \mathrm{~N}-\mathrm{HCl}$ on individual cultures was reproducible, and it therefore seemed that the acid stability of the type-specific antigen was a constant character of a strain. Cultures which yielded active extracts with $0.01 \mathrm{~N}-\mathrm{HCl}$ but not with $0.05 \mathrm{~N}$ were found in most serotypes, but were particularly common in types 1 and 5 (Table 1). With $0 \cdot 2 \mathrm{~N}-\mathrm{HCl}$ all extracts were serologically inactive, except that of the type strain of type 8.

The inhibition of the precipitin reaction by a substance extracted from the organism with strong acid was type-specific. An extract was prepared with $0.2 \mathrm{~N}-\mathrm{HCl}$ from a representative of each serotype. Only the type 8 extract gave a precipitin reaction with the homologous serum. Mixtures were prepared of equal quantities of each of these extracts and each of the type sera. These were tested in capillary tubes 
with an active (0.05 $\mathrm{N}-\mathrm{HCl})$ extract of an organism of type homologous with that of the serum. It will be seen (Table 3) that the $0.2 \mathrm{~N}$ extract inhibited the reaction between serum and the $0.05 \mathrm{~N}$ extract of homologous type, but with two exceptions not the reactions in other types. Type 5 showed a one-way cross with type 9 , and type 6 with type 3 , and there were corresponding cross-reactions in the inhibition test; and the $0 \cdot 2 \mathrm{~N}-\mathrm{HCl}$ extract of type 8 , which was itself serologically active, did not inhibit the reaction between the $0.05 \mathrm{~N}$ extract of the same type and its homologous serum.

The distribution of type antigen in different parts of the bacterium was next examined. The cell-wall fractions of mechanically disrupted cultures were separated and treated with ribonuclease and deoxyribonuclease. They were then extracted with acids of various strengths and yielded type-specific antigen with the same acid sensitivity as that obtained from untreated organisms.

Table 4. Ethanol precipitation and acid sensitivity of type-specific polysaccharide in the soluble cellular material obtained by mechanical disruption of Streptococcus faecalis

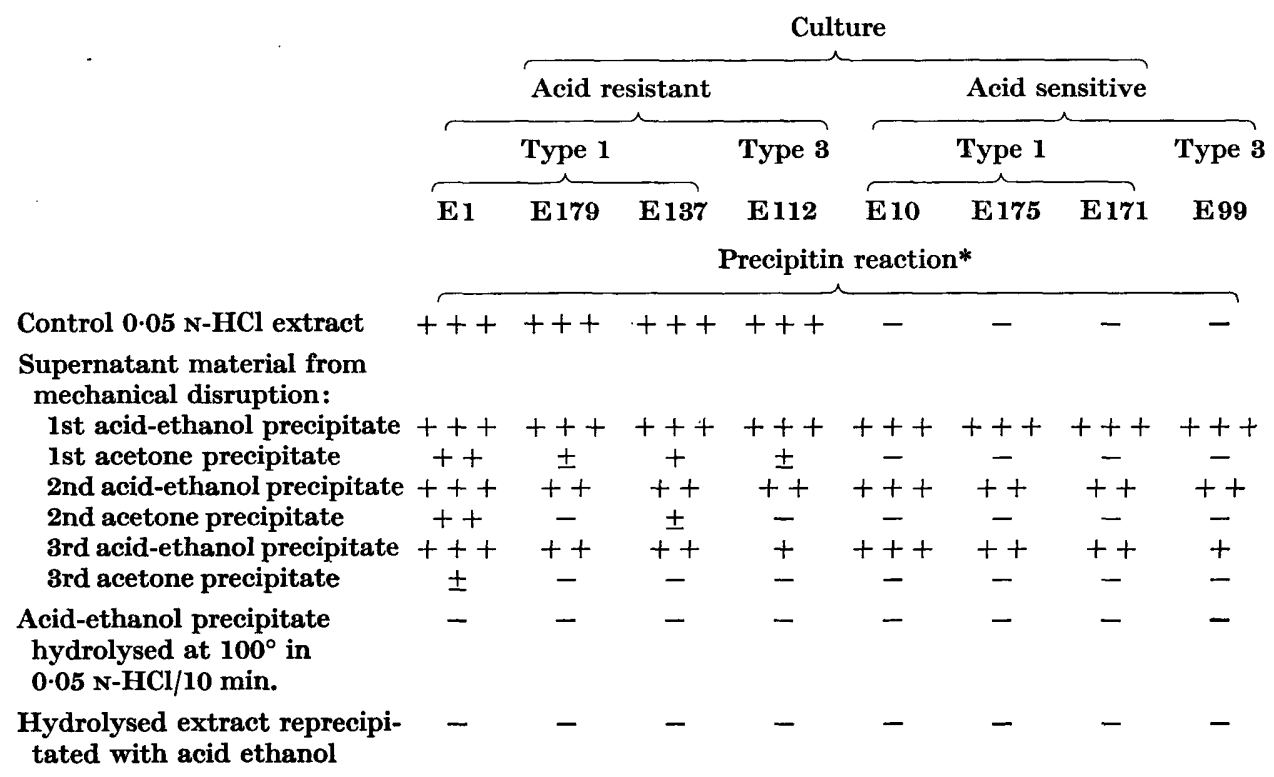

$*+$ to $+++=$ strength of precipitin reaction with homologous serum.

However, the untreated supernatant fluid from the disrupted bacteria also gave a strong type-specific precipitation reaction. This finding contrasted with our experience with Streptococcus pyogenes, where the cell-wall antigens did not appear in the supernatant fluid from disrupted bacteria. Eight strains, four of which gave an active extract with $0.05 \mathrm{~N}-\mathrm{HCl}$ and four of which did not, were disintegrated mechanically. Each supernatant fluid was precipitated first with ethanol and then with acetone. The two precipitates were each dissolved in buffer and re-precipitated three times to eliminate cross-contamination as much as possible, before being tested against the homologous serum (Table 4). The ethanol-insoluble fraction from all 8 strains gave a strong precipitin reaction with the corresponding type anti- 
serum. There were some weak positive reactions between the serum and the acetoneinsoluble fractions from the four strains which normally resisted acid hydrolysis, but these may have been due to material carried over from the ethanol-insoluble fraction, since the reactions disappeared after further re-precipitation with acid ethanol. None of the acetone-insoluble fractions had any inhibitory action on the precipitin reaction of the corresponding ethanol-insoluble fraction and its specific serum.

The ethanol-insoluble fractions from the supernatant fluids of disrupted suspensions were then treated with $0.05 \mathrm{~N}-\mathrm{HCl}$. All of them, whether derived from organisms which did or did not yield active extracts from whole organisms with acid of the same strength, were rendered inactive by this treatment (Table 4).

Centrifuged deposits of bacteria were therefore digested with trypsin to see whether a surface protein was protecting the cell-wall polysaccharide of some strains from the action of strong acid; no constant increase in susceptibility to $0.05 \mathrm{~N}-\mathrm{HCl}$ resulted from this treatment.

\section{DISCUSSION}

Over nine-tenths of the group D streptococci we isolated from human lesions were Streptococcus faecalis (Maxted \& Fraser, 1964). The success in typing 92\% of $S$. faecalis cultures with eight sera suggests that this method might be useful in epidemiological studies of hospital infections with this organism. The manufacture of typing sera presents little difficulty, and the typing technique is easily done when $0.01 \mathrm{~N}-\mathrm{HCl}$ is used for extraction.

Elliott (1960) and Sharpe (1964) both found that the type-specific carbohydrate of some strains of Streptococcus faecalis was destroyed by heating to $100^{\circ}$ in the presence of strong acid; and Bleiweis \& Krause (1965) showed, with one type 1 strain, that hydrolysis of the carbohydrate at $\mathrm{pH} 1.5$ resulted in the formation of a dialysable inhibitor of the precipitin reaction between the type antigen and its homologous antibody. In our experience many cultures give serologically inactive extracts when treated with $0.05 \mathrm{~N}-\mathrm{HCl}(\mathrm{pH} \mathrm{1.6})$. The effect of this strength of $\mathrm{HCl}$ appears to be to hydrolyze part of the type-specific polysaccharide to a substance which, although inactive in the precipitin reaction, retains the serological determinants of the antigen. It is therefore able to block the precipitation reaction between antibody and unhydrolyzed antigen. When sufficiently strong $\mathrm{HCl}$ is used (e.g. $0 \cdot 2 \mathrm{~N}$ ) the type-specific antigen of nearly all $S$. faecalis strains is rendered inactive, and in many cases the extracts consist almost entirely of acetone-insoluble inhibitory material.

There appears, however, to be a difference between the organisms which usually yield active extracts with $0.05 \mathrm{~N}-\mathrm{HCl}$ and those which do not. The reason for this is not clear. Type-specific antigen obtained from the cell contents of disrupted organisms without chemical treatment appears to be uniformly sensitive to acid of this strength. This suggests that the antigen of the intact organism is protected in some way from the action of the strong acid. 


\section{REFERENCES}

Bleiweis, A. S. \& Krause, R. M. (1965). The cell walls of group D streptococci. I. The immunochemistry of the type 1 carbohydrate. J. exp. Med. 122, 237.

ELrrotT, S. D. (1960). Type 1 group polysaccharides of group D streptococci. J. exp. Med. $111,621$.

Maxted, W. R. (1948). Preparation of streptococcal extracts for Lancefield grouping. Lancet, ii, 255.

MaXted, W. R. \& Fraser, C. A. M. (1964). The serological typing of Streptococcus faecalis. Zentbl. Bakt.ParasitKde, I. Ref., 196, 76.

Sharpe, M. E. (1964). Serological types of Streptococcus faecalis and its varieties and their cell wall type antigen. J. gen. Microbiol. 36, 151.

Sharpe, M. E. \& Shatrock, P. M. F. (1952). The serological typing of group D streptococci associated with outbreaks of neonatal diarrhoea. J. gen. Microbiol. 6, 150. 